\title{
Pengaruh Profitabilitas, Ukuran Perusahaan dan Kepemilikan Publik pada Pengungkapan Corporate Social Responsibility
}

\author{
Anak Agung Windra Lorna Pramesti ${ }^{1}$ \\ Fakultas Ekonomi dan Bisnis \\ Universitas Udayana, Indonesia \\ Email: aawindralorna@gmail.com
}

\author{
I Gusti Ayu Nyoman Budiasih2 \\ Fakultas Ekonomi dan Bisnis \\ Universitas Udayana, Indonesia
}

\begin{abstract}
ABSTRAK
Penelitian bertujuan untuk pengaruh profitabilitas terhadap pengungkapan Corporate Social Responsibility, pengaruh ukuran perusahaan terhadap pengungkapan Corporate Social Responsibility, pengaruh kepemilikan publik terhadap pengungkapan Corporate Social Responsibility. Penelitian dilakukan pada perusahaan pertambangan yang terdaftar res $\mathrm{mi}$ di Bursa Efek Indonesia (BEI) thun 2015 - 2017. Populasi dala m penelitianini adalah seluruh perusahaan pertambangan yang terdaftar di Bursa Efek Indonesia dari tahun 2015-2017. Sa mpel yang digunakan dengan purposive sampling. Teknik analisis da ta yang digunakan adalah analisis regresi linear berga nda. Ha sil penelitian menunjukkan bahwa profitabilitas, ukuran perusahaan dankepemilikan publik berpengaruh positif pada pengungkapan Corporate Social Responsilibility.
\end{abstract}

Kata Kunci: Profitabilitas; Ukuran Perusahaan; Kepemilikan Publik; Corporate Social Responsibility.

\section{Effect of Profitability, Company Size and Public} Ownership on Corporate Social Responsibility Disclosures

\begin{abstract}
This study aims to influence profitability on corporate social responsibility disclosure, the effect of company size on corporate social responsibility disclosure, the effect of public ownership on corporate social responsibility disclosure. The study was conducted on mining companies thatwere officially listed on the Indonesia Stock Exchange (BEI) in 2015-2017. The population in this study were all mining companies listed on the Indonesia Stock Exchange from 2015-2017. The sample used by purposive sampling. The data analysis technique used is multiple linear regression analysis. The results showed that profitability, company size and public ownership had a positive effect on the disclosure of Corporate Social Responsibility.
\end{abstract}

Keywords: Profitability; Company Size; Public Ownership; Corporate Social Responsibility.

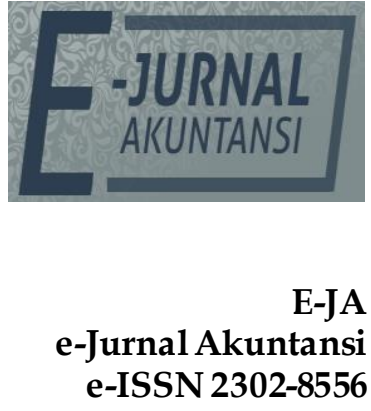

Vol. 30 No. 4 Denpasar, April 2020

Hal.1006-1018

Artikel Masuk: 8 Januari 2020

Tanggal Diterima: 30 Januari 2020 
PENDAHULUAN

Program Corporate Social Responsibility (CSR) merupakan investasi jangka panjang bagi perusahaan demi pertumbuhan dan keberlanjutan (sustainability) perusahaan dan bukan lagi dilihat sebagai sarana biaya (cost centre) melainkan sebagai sarana meraih keuntungan (profit centre). Pengungkapan CSR perusahaan mempengaruhi reputasi, keunggulan kompetitif dan menajemen resiko suatu perusahaan. Fenomena kerusakan lingkungan juga terjadi di lokasi penambangan timah inkonvensional di pantai pulau Bangka - Belitung menjadi salah satu bukti kelalaian perusahaan pada lingkungannya dan tidak dapat ditentukan siapakah pihak yang bertanggung jawab atas kerusakan yang terjadi karena kegiatan penambangan dilakukan oleh penambangan rakyat tak berizin yang mengejar setoran pada PT. Timah Tbk. sebagai akibat penambangan inkonvensional tersebut terjadi pencemaran air permukaan laut dan perairan umum, lahan menjadi tandus, terjadi abrasi pantai, dan kerusakan laut (Ambadar, 2008).

Penelitian mengenai pengungkapan CSR sampai saat ini telah banyak dilakukan. Banyak faktor yang mempengaruhi CSR seperti profitabilitas, ukuran perusahaan, dan kepemilikan publik, hasil penelitian tentang faktor-faktor tersebut memunculkan hasil yang beragam dan menarik untuk dikaji lebih dalam. Profitabilitas merupakan rasio yang mengukur kemampuan entitas dalam menghasilkan laba pada tingkat penjualan, aset dan ekuitas. Ukuran perusahaan adalah skala yang digunakan dalam menentukan besar kecilnya suatu perusahaan. Perusahaan yang skalanya besar biasanya cenderung lebih banyak mengungkapkan CSR daripada perusahaan yang mempunyai skala kecil (Sari, 2012). Perusahaan go public dan telah terdaftar dalam BEI adalah perusahaan - perusahaan yang memiliki proporsi kepemilikan saham oleh publik, yang artinya bahwa semua aktivitas dan keadaan perusahaan harus dilaporkan dan diketahui oleh publik sebagai salah satu bagian pemegang saham. Akan tetapi tingkat kepemilikan sahamnya berbeda-beda satu sama lain (Retno \& Priantinah, 2012). Perusahaan hendaknya memperhatikan kepentingan stakeholder, karena stakeholder adalah pihak yang mempengaruhi baik secara langsung maupun tidak langsung atas aktivitas serta kebijakan yang diambil dan dilakukan perusahaan. Jika hal ini tidak dilakukan akan menuai protes. Untuk itu, perusahaan hendaknya menjaga reputasi yaitu dengan cara menggeser pola orientasi (tujuan) yang semula semata-mata diukur dengan economic measurement yang cenderung shareholder orientation ke arah memperhitungkan faktor sosial sebagai wujud kepedulian dan keberpihakan terhadap masalah sosial masyarakat (stakeholder orientataion) (Hadi, 2011).

Teori legitimasi didasarkan pada pengertian kontrak sosial yang di implikasikan antara institusi sosial dan masyarakat (Ahmad \& Sulaiman, 2004). Teori tersebut diperlukan oleh institusi untuk mencapai tujuan dengan masyarakat luas. legitimasi perusahaan dimata stakeholder merupakan faktor signifikan untuk mendukung citra dan reputasi perusahaan dimata stakeholder (Hadi, 2011). Dengan demikian, maka pengungkapan informasi CSR merupakan investasi jangka panjang dan memiliki manfaat dalam meningkatkan image dan 
legitimasi, sehingga dapat dijadikan sebagai basis konstruksi strategi perusahaan.

Pertanggungjawaban sosial perusahaan atau Corporate Social Responsibility (CSR) adalah mekanisme bagi suatu organisasi untuk secara sukarela mengintegrasikan perhatian terhadap lingkungan dan sosial ke dalam operasinya dan interaksinya dengan stakeholders, yang melebihi tanggungjawab organisasi di bidang hukum (Anggraini, 2006). Menurut Anggraini (2006), mengidentifikasi beberapa hal yang berkaitan dengan pelaporan CSR perusahaan yaitu lingkungan, energi, praktik bisnis yang wajar, sumber daya manusia, dan produk. ISO 26000 Guidance Standar on Social Responsibility mencakup 7 isu pokok dan 37 item dari pengungkapan tanggung jawab social , tujuh kategori dalam ISO 26000 tersebut yaitu struktur organisasi, HAM, praktik perbankan, lingkungan, praktik operasi, isu konsumen, pelibatan pengembangan masyarakat (Fahmi, 2015).

Saat ini Corporate Social Responsibility (CSR) memang menjadi trend di Indonesia. Banyak orang berbicara tentang CSR dan semakin banyak perusahaan yang melaksanakan program tersebut. Menurut Kuntari \& Sulistyani (2007), ad a tiga pendekatan dalam pelaporan kinerja sosial yaitu pemeriksaan sosial, laporan sosial, pengungkapan sosial dalam laporan tahunan. Rasio profitabilitas adalah sekelompok rasio yang menunjukkan gabungan efek-efek dari likuiditas, manajemen aktiva, dan hutang pada hasil-hasil operasi (Brigham \& Houston, 2010: 107). Hubungan antara pengungkapan sosial perusahaan dan profitabilitas perusahaan telah menjadi postulat untuk mengembangkan pandangan bahwa tanggapan sosial memerlukan gaya manajerial yang sama seperti apa yang perlu dilakukan untuk membuat perusahaan menghasilkan laba (Zaenuddin, 2007).

Ukuran perusahaan merupakan ukuran mengenai besar kecilnya suatu perusahaan. Secara umum sebuah perusahaan besar tidak terlepas dari tekanan untuk melakukan pertanggungjawaban sosial sehingga akan mengungkapkan informasi lebih banyak dan lebih luas dibandingkan dengan perusahaan kecil (Putra, 2011). Menurut Ebiringa, Yadirichukwu, Chigbu \& Ogochukwu (2013), bahwa ukuran perusahaan akan berhubungan dengan kegiatan tanggung ja wab sosial, karena perusahaan besar lebih mungkin perlu dikritisi oleh kedua kelompok kepentingan umum dan kelompok sosial. Kepemilikan saham oleh publik menggambarkan tingkat kepemilikan perusahaan oleh masyarakat publik. Kepemilikan saham oleh publik adalah jumlah saham perusahaan yang dimiliki oleh publik, yaitu individu atau institusi yang memiliki kepemilikan saham di bawah lima persen yang berada diluar manajemen dan tidak memiliki hubungan istimewa dengan perusahaan (Hanafi \& Halim, 2012). Perusahaan yang go public dituntut untuk lebih transparan mengungkap informasi yang memadai dan relevan dengan tujuan menciptakan pasar modal yang efisien. Oleh karena itu, semakin tinggi proporsi sahamyang dimiliki publik maka tingkat kelengkapan pengungkapan laporan tahunan akansemakin tinggi pula. 


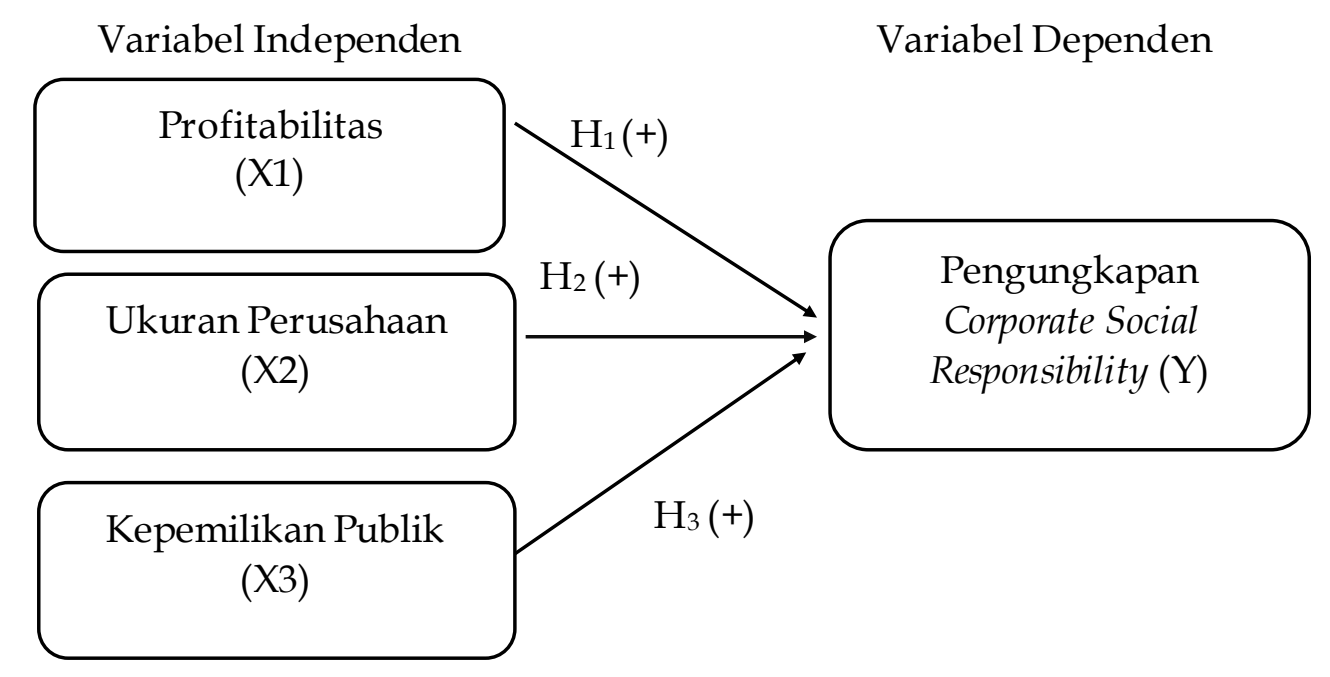

Sumber: Data Penelitia, 2019

Gambar 1. Kerangka Konseptual

Teori stakeholder menyatakan bahwa semakin besar profit yang dihasilkan oleh perusahaan, maka akan semakin besar pula pengungkapan CSR yang dilakukan karena sebagai bukti akuntabilitas kepada stakeholder dan meyakinkan bahwa aktivitas perusahaan sesuai dengan norma dan nilai sosial di lingkungan masyarakat (Nugroho \& Yulianto, 2015). Pelaksanaan CSR ini dianggap akan meningkatkan penjualan dan akan berpengaruh pada peningkatan profit yang akan didapat oleh perusahaan.

Profit yang lebih tinggi otomatis mewajibkan perusahaan untuk lebih meningkatkan pelaksanaan CSR, dengan kata lain profitabilitas mempunyai pengaruh terhadap luas pengungkapan CSR yang dilakukan oleh perusahaan. Oleh karena itu, dapat dinyatakan bahwa semakin tinggi tingkat profitabilitas yang dihasilkan perusahaan maka pngungkapan CSR akan cenderung semakin besar. Hal ini terbukti dari hasil penelitian dari Indraswari dan Astika (2014), Veronica dan Sumin (2010) yang menytakan bahwa profitabilitas berpengaruh positif terhadap pengungkapan CSR.

Hasil penelitian dari Purwaningsih \& Suyanto (2015) dan Fahrizqi (2010) juga menyatakan bahwa profitabilitas memiliki pengaruh positif terhadap pengungkapan CSR. Fahrizqi (2010) menyatakan bahwa peningkatan profitabilitas perusahaan akan meningkatkan dan memperluas informasi pengungkapan tanggung jawab sosial perusahaan. Karena semakin besar perusahaan memperoleh keuntungan, maka akan memberikan keleluasaan kepada manajemen perusahaan untuk melakukan CSR sebagai srategi menjaga hubungan baik dengan stakeholder lainnya. Berdasarkan uraian diatas, maka hipotesis dalam penelitian ini adalah:

$\mathrm{H}_{1}$ : Profitabilitas berpengaruh positif pada pengungkapan Corporate Social Responsibility.

Teori legitimasi memiliki alasan tentang hubungan ukuran dan pengungkapan. Perusahaan yang lebih besar melakukan aktivitas yang lebih 
banyak sehingga memiliki pengaruh yang lebih besar terhadap masyarakat, memiliki lebih banyak pemegang saham yang punya perhatian terhadap program sosial yang dilakukan perusahaan dan laporan tahunan merupakan alat yang efisien untuk mengkomunikasikan informasi ini (Cowen, Ferreri, \& Parker, 1987). Ukuran perusahaan juga merupakan variabel yang penting dalam praktik CSR dan berperan seperti barometer yang menjelaskan mengapa perusahaan terlibat dalam praktik CSR. Selain itu, juga dinyatakan bahwa CSR hanya akan tampak berbeda apabila konsep CSR terintegrasi dengan prinsip dan praktik perusahaan dan ketika kemajuan pelaksanaan CSR secara teratur dilakukan monitoring (Purwanto, (2011). Pernyataan tersebut sejalan dengan penelitian Siregar \& Utama (2008), semakin besar ukuran perusahaan, informasi investasi saham semakin banyak.

Berbagai penelitian yang berhasil membuktikan hubungan positif antara variabel ukuran perusahaan dan pengungkapan CSR antara lain dilakukan oleh Sembiring (2005) serta Rahmawati (2005), Nofandrilla (2008) menemukan pengaruh positif pada ukuran perusahaan terhadap pengungkapan tanggung jawab sosial perusahaan. Tetapi tidak semua penelitian mendukung hubungan antara ukuran perusahaan dengan pengungkapan CSR perusahaan. Ada penelitian yang tidak berhasil menunjukan hubungan positif antar kedua variabel tersebut, yaitu penelitian yang dilakukan oleh (Rahman \& Widy asari, 2008). Karena ukuran perusahaan mampu menjelaskan berbagai macam variasi pengungkapan sosial yang digunakan perusahaan dalam laporan tahunan perusahaan. Berdasarkan uraian diatas, maka hipotesis dalam penelitian ini adalah:

$\mathrm{H}_{2}$ : Ukuran perusahaan berpengaruh positif pada pengungkapan Corporate Social Responsibility.

Teori stakeholder menyatakan bahwa kepemilikan saham publik memiliki peran untuk mempengaruhi perusahaan dalam melakukan pengungkapan aktivitas sosialnya sedangkan perusahaan akan berusaha memenuhi segala kebutuhan para stakeholder termasuk kebutuhan informasi pengungkapan kegiatan sosial perusahaan. Selain itu menurut teori legitimasi perusahaan yang memiliki kepemilikan publik yang tinggi pastinya akan lebih memperhatikan pengungkapan tanggung jawab sosial karena perusahaan semakin banyak memegang kepercayaan masyarakat dan masyarakat pastinya akan memperhatikan apakah perusahaan tempatnya berinvestasi melakukan tindakan sosial yang mensejahterakan masyarakat dan lingkungan sekitar perusahaan. Sehingga kepemilikan publik yang tinggi akan juga meningkatkan pengungkapan tanggung jawab sosial perusahaan.

Perusahaan go public dan telah terdaftar dalam BEI adalah per usahaanperusahaan yang memiliki proporsi kepemilikan saham oleh publik, yang artinya bahwa semua aktivitas dan keadaan perusahaan harus dilaporkan dan diketahui oleh publik sebagai salah satu bagian pemegang saham. Akan teta pi tingkat kepemilikan sahamnya berbeda-beda satu sama lain. Penelitian Puspitasari (2009) menyatakan semakin besar komposisi saham perusahaan yang dimiliki publik, maka dapat memicu perusahaan melakukan 
pengungkapan secara luas termasuk pengungkapan CSR hal ini sependapat dengan penelitian yang dilakukan oleh Dewi (2008), bertolak belakang d engan hal tersebut hasil penelitian yang dilakukan oleh Wakidi \& Siregar (2011) menunjukkan bahwa kepemilikan saham publik tidak berpengaruh pada pengungkapan CSR.

Kepemilikan publik dalam hal ini yang dimaksud adalah proporsi saham yang dimiliki oleh masyarakat dengan pihak internal perusahaan. Oleh karena itu, semakin tinggi porsi saham yang dimiliki oleh publik maka tingkat kelengkapan dan keluasan pengungkapan laporan akan tinggi pula. Berdasarkan uraian diatasmaka hipotesis dalam penelitian ini adalah:

$\mathrm{H}_{3}$ : Kepemilikan publik berpengaruh positif pada pengungkapan Corporate Social Responsibility.

\section{METODE PENELITIAN}

Lokasi penelitian ini adalah perusahaan pertambangan yang terdaftar di situs resmi Busa Efek Indonesia (BEI) tahun 2015-2017, yaitu dengan mengakses www.idx.co.id. Objek dalam penelitian ini adalah pengungkapan Corporate Social Responsibilitypada perusahaan pertambangan yang terdaftar di Bursa Efek Indonesia tahun 2015-2017. Variabel yang digunakan dalam penelitian ini terdiri dari satu variabel dependen dan tiga variabel independen, yaitu variabel dependen/terikat (Y) adalah pengungkapan Corporate Social Responsibility. Variabel independen/bebas $(X)$ adalah profitabilitas $\left(X_{1}\right)$, ukuran perusahaan $\left(\mathrm{X}_{2}\right)$ dan kepemilikan publik $\left(\mathrm{X}_{3}\right)$.

Pengungkapan CSR diatur dalam Undang-undang Perseroan Terbatas No. 40 tahun 2007 Pada pasal 66 ayat (2) yang menyebutkan bahwa semua perseroan wajib untuk melaporkan pelaksanaan tanggung jawab tersebut di Laporan Tahunan. Oleh karena itu perusahaan dituntut untuk menerapkan CSR dalam program kerjanya dan mengungkapkan CSR pada laporan tahunan perusahaan. Standar pengungkapan CSR yang berkembang di Indonesia merujuk pada standar yang diterapkan GRI (Global Reporting Initiative). Total indikator yang terdapat dalam GRI mencapai 91 item (www.globalrporting.org).

$\mathrm{CSRI}=\overline{\mathrm{Nj}}$

Keterangan:

$\mathrm{CSRI}_{\mathrm{j}}=$ Corporate Social Responsibility Disclosure Index Perusahaan $\mathrm{j}$

$\mathrm{N}_{\mathrm{j}} \quad=$ Jumlah item untuk perusahaan $\mathrm{j}, \mathrm{n}_{\mathrm{j}}=91$ (skor maksimal)

$\mathrm{X}_{\mathrm{i}}=$ Jumlah total pengungkapan CSR. $1=$ jikaitem diungkapkan; $0=$ jika item tidak diungkapkan. Sehingga, $0<\mathrm{CSRI}_{\mathrm{j}}<1$

Brigham dan Houston (2011), profitabilitas adalah hasil akhir dari serangkaian kebijakan dan keputusan manajemen, dimana kebijakan dan keputusan ini menyangkut pada sumber dan penggunaan dana dalam menjalankan operasional perusahaan yang terangkum dalam laporan neraca dan unsur dalam neraca. Semakin besar ROA menunjukkan kinerja perusahaan yang semakin baik karena tingkat kembalian (return) yang semakin besar (Natalia \& Laksono, 2013). Variabel profitabilitas dalam penelitian ini dihitung dengan menggunakan rumus return on asset (ROA) Sumanti \& Mangantar (2015): 
$\mathrm{ROA}=\frac{\text { Lababersih (setelahpajak) }}{\text { Total Asset }} \times 100 \%$

Ukuran perusahaan merupakan skala yang digunakan untuk menetukan

besar kecilnya suatu perusahaan. Konsisten dengan penelitian Wijaya (2012) pada penelitian ini ukuran perusahaan diproksikan dengan log natural total aset, tujuannya adalah untuk mengurangi perbedaan yang signifikan antara besar atau kecilnya perusahaan sehingga data dari total aset dapat terdistribusi normal. Rumus yang digunakan untuk mengukur ukuran perusahaan adalah sebagai berikut :

Ukuran Perusahaan $=\log N$ (Total Aset)

Kepemilikan publik adalah jumlah saham yang dimiliki pihak eksternal perusahaan bukan dividu maupun lembaga terhadap saham yang ada di perusahaan di Indonesia. Kepemilikan saham publik dapat dilihat dalam laporan tahunan perusahaan. Rumus pengukuran untuk kepemilikan saham publik yang diadopsi dari penelitian Oktariani (2013) sebagai berikut:

$\mathrm{KSP}=\frac{\text { Jumlah sahamyang dimiliki masyarakat }}{\text { Jumlah sahamyang beredar }} \times 100 \%$

\section{HASIL DAN PEMBAHASAN}

Objek penelitian ini adalah perusahaan pertambangan yang terdaftar pada BEI periode tahun 2015-2017. Jumlah Perusahaan Pertambangan yang terdaftar di BEI periode tahun 2015-2017 sejumlah 47. Perusahaan pertambangan dipilih karena perusahaan pertambangan merupakan salah satu jenis perusahaan yang kegiatan operasinya berpotensi memberikan dampak negatif secara langsung pada lingkungan sekitar lokasi kegiatan pertambangan.

Tabel 1. Proses Seleksi Sampel dengan Purposive Sampling

\begin{tabular}{lc}
\hline \multicolumn{1}{c}{ Kriteria } & Jumlah \\
\hline Perusahaan Pertambangan yang terdaftar di BEI pada tahun2015-2017 & 47 \\
$\begin{array}{l}\text { Perusahaan pertambangan yang tidak mengeluarkan laporan tahunan } \\
\text { selama tahun 2015-2017 secara berturut-turut }\end{array}$ & $(20)$ \\
$\begin{array}{l}\text { Perusahaan pertambangan yang tidak menyajikan data secara lengkap } \\
\text { mengenai ketiga variabel }\end{array}$ & $(12)$ \\
Perusahaan Pertambangan yang menjadi sampel (15X3) & 45 \\
\hline
\end{tabular}
Sumber: Data Penelitian, 2019

Berdasarkan pengolahan data SPSS tentang pengujian statistik deskriptif mengenai variabel pengungkapan Corporate Social Responsibility, profitabilitas, ukuran perusahaan dan kepemilikan publik maka didapatkan hasil analisis yang disajikan dalam Tabel 2.

Tabel 2. Statistik Deskriptif Variabel Penelitian

\begin{tabular}{llllll}
\hline & $\mathrm{N}$ & Minimum & Maximum & Mean & Std. Deviation \\
\hline CSRDI & 45 & 0,0220 & 0,9560 & 0,188523 & 0,1889162 \\
ROA & 45 & 0,0012 & 0,3941 & 0,091969 & 0,1008122 \\
SIZE & 45 & 22,9511 & 30,7215 & 28,332085 & 1,9444195 \\
KSP & 45 & 0,55 & 63,92 & 22,5538 & 18,38172 \\
Valid N (listwise) & 45 & & & & \\
\hline
\end{tabular}

Sumber: Data Penelitian, 2019 
Berdasarkan Tabel 2. dapat dijelaskan bahwa variabel terikat pengungkapan Corporate Social Responsibility memiliki nilai minimum sebesar 0,0220 pada PT Darma Henwa Tbk di periode pengamatan 2015, sedangkan nilai maksimum sebesar 0,9560 pada PT Bukit Asam Tbk di periode pengamatan 2015. Pengungkapan Corporate Social Responsibility perusahaan memiliki mean atau nilai rata-rata sebesar 0,188523 dan standar deviasi sebesar 0,1889162.

Variabel bebas profitabilitas memiliki nilai minimum 0,0012 pada PT Darma Henwa Tbk di periode pengamatan 2015 dan 2016, sedangkan nilai maksimum sebesar 0,3941 pada PT Baramulti Sukses Sarana Tbk di periode pengamatan 2017. Profitabilitas memiliki mean atau nilai rata-rata sebesar 0,091969 dan standar deviasi sebesar 0,1008122. Variabel bebas ukuran perusahaan memiliki nilai minimum 22,9511 pada PT Timah (Persero)Tbk di periode pengamatan 2015, sedangkan nilai maksimum sebesar 30,7215 pada PT Bukit Asam Tbk di periode pengamatan 2017. Ukuran perusahaan memiliki mean atau nilai rata-rata sebesar 28,332085 dan standar deviasi sebesar 1,9444195. Variabel bebas kepemilikan saham publik memiliki nilai minimum 0,55 pad a PT Adaro Energy Tbk di periode pengamatan 2015, sedangkan nilai maksimum sebesar 63,92 pada PT Darma Henwa Tbk di periode pengamatan 2017. Kepemilikan saham publik memiliki mean atau nilai rata-rata sebesar 22,5538 dan standar deviasi sebesar 18,38172.

Analisis regresi linier berganda digunakan untuk mengetahui arah dan besarnya pengaruh Profitabilitas, ukuran perusahan, dan kepemilikan publik pada pengungkapan Corporate Social Responsibility perusahaan pertambangan yang terdaftar di Bursa Efek Indonesia.

Hasil menunjukkan seluruh variabel memiliki nilai signifikansi kurang dari 0,05. Hal ini berarti bahwa terdapat pengaruh yang signifikan dari variabel bebas tehadap variabel terikatnya. Hasil pengujian pengaruh masing-masing variabel independen yaitu, Profitabilitas (ROA) $\left(\mathrm{X}_{1}\right)$ terhadap Corporate Social Responsibility (Y) Berdasarkan Tabel 3, dapat dilihat bahwa nilai signifikansi (ROA) sebesar 0,000<0,05, maka $\mathrm{H}_{0}$ ditolak, yang berarti ada pengaruh signifikan antara profitabilitas terhadap pengungkapan Corporate Social Responsibility pada Perusahaan Pertambangan di BEI periode 2015-2017. Ukuran perusahaan (SIZE) $\left(\mathrm{X}_{2}\right)$ terhadap Corporate Social Responsibility $(\mathrm{Y})$ berdasarkan Tabel 3.

Tabel 3. Hasil Analisis Regresi Linier Berganda

\begin{tabular}{ccccccc}
\hline & & \multicolumn{2}{c}{$\begin{array}{c}\text { Unstandardized } \\
\text { Coefficients }\end{array}$} & $\begin{array}{c}\text { Standardized } \\
\text { Coefficients }\end{array}$ & & \\
\cline { 3 - 4 } & & & & & & \\
& Model & B & Std. Error & Beta & t & Sig. \\
\hline 1 & (Constant) & 0,036 & 0,101 & & 0,358 & 0,722 \\
& ROA & 0,421 & 0,108 & 0,437 & 3,892 & 0,000 \\
& SIZE & 0,375 & 0,105 & 0,414 & 3,589 & 0,001 \\
& KSP & 0,227 & 0,109 & 0,237 & 2,090 & 0,043 \\
\hline
\end{tabular}

Sumber: Data Penelitian, 2019

Berdasarkan hasil analisis pada Tabel 3. maka persamaan regresi yang digunakan dalam penelitian ini dapat ditulis sebagai berikut.

$$
Y=0,036+0,421 X_{1}+0,375 X_{2}+0,227 X_{3}
$$


Keterangan :

$\mathrm{Y}=\quad$ Corporate Social Responsibility

$\mathrm{X}_{1}=$ Profitabilitas

$\mathrm{X}_{2}=$ Ukuran perusahaan

$\mathrm{X}_{3}=$ Kepemilikan publik

dapat dilihat bahwa nilai signifikansi (SIZE) sebesar 0,001<0,05, maka $\mathrm{H}_{0}$ ditolak, yang berarti ada pengaruh signifikan antara ukuran perusahaan terhadap pengungkapan Corporate Social Responsibility pada Perusahaan Pertambangan di BEI periode 2015-2017. Kepemilikan publik $\left(X_{3}\right)$ terhadap Corporate Social Responsibility (Y) Berdasarkan Tabel 3, dapat dilihat bahwa nilai signifikansi kepemilikan publik sebesar $0,043<0,05$, maka $\mathrm{H}_{0}$ ditolak, yang berarti ada pengaruh signifikan antara kepemilikan publik terhadap pengungkapan Corporate Social Responsibility pada Perusahaan Pertambangan di BEI periode 2015-2017.

Hasil penelitian menunjukkan bahwa profitabilitas yang diproksikan dengan ROA berpengaruh positif pada pengungkapan Corporate Social Responsibility perusahaan pertambangan di BEI periode 2015-2017. Jadi hasil penelitian ini sesuai dengan hipotesis pertama yaitu profitabilitas berpengaruh positif pada pengungkapan Corporate Social Responsibility perusahaan pertambangan di BEI periode 2015-2017. Hasil penelitian ini sesuai dengan penelitian sebelumnya yaitu penelitian Indraswari \& Astika (2014), Purwaningsih \& Suyanto (2015) dan (Fahrizqi, 2010). Penelitian sebelumnya membuktikan secara parsial ROA memiliki pengaruh signifikan terhadap pengungkapan Corporate Social Responsibility. Indraswari \& Astika (2014) membuktikan koefisien regresi bernilai positif yang berarti bahwa profitabilitas memiliki pengaruh yang positif terhadap jumlah pengungkapan CSR yang dilakukan peusahaan masyarakat.

Profit yang lebih tinggi otomatis mewajibkan perusahaan untuk lebih meningkatkan pelaksanaan CSR, dengan kata lain profitabilitas mempunyai pengaruh terhadap luas pengungkapan CSR yang dilakukan oleh perusahaan. Hasil penelitian ini menunjukan bahwa ROA berpengaruh positif dan signifikan. Artinya setiap kali ROA mengalami peningkatan maka pengungkapan CSR mengalami peningkatan, hasil ini mengindikasikan bahwa peningkatan keuntungan oleh perusahaan akan meningkatkan dan memperluas informasi pengungkapan tanggung jawab sosial perusahaan.

Hasil penelitian menunjukkan bahwa ukuran perusahaan yang diproksikan dengan ukuran ukuran perusahaan berpengaruh positif pada pengungkapan Corporate Social Responsibility perusahaan pertambangan di BEI periode 2015-2017. Jadi hasil penelitian ini mendukung hipotesis kedua yaitu ukuran perusahaan berpengaruh positif pada pengungkapan Corporate Social Responsibility perusahaan pertambangan di BEI periode 2015-2017. Hasil penelitian ini sesuai dengan penelitian sebelumnya Sembiring (2005), Rahmawati (2005) serta (Nofandrilla, 2008). Penelitian sebelumnya membuktikan secara parsial ukuran perusahaan memiliki pengaruh positif terhadap pengungkapan Corporate Social Responsibility. Sembiring (2005) menyatakan secara teoritis 
perusahaan besar tidak akan lepas dari tekanan, dan perusahaan yang lebih besar dengan aktivitas operasi dan pengaruh yang lebih besar terhadap masyarakat mungkin akan memiliki pemegang saham yang memperhatikan program sosial yang dibuat perusahaan sehingga pengungkapan tanggung jawab sosial perusahaan akan semakin luas.

Perusahaan yang berukuran lebih besar melakukan aktivitas yang lebih banyak sehingga memiliki pengaruh yang lebih besar terhadap masyarakat, memiliki lebih banyak pemegang saham yang punya perhatian terhadap program sosial yang dilakukan perusahaan. Hasil penelitian ini menunjukan bahwa ukuran perusahaan berpengaruh positif. Artinya pertanggungjawaban sosial dipengaruhi oleh ukuran perusahaan dimana perusahaan besar cenderung mengungkapkan pertanggungjawaban sosial yang lebih luas.

Hasil penelitian menunjukkan bahwa kepemilikan publik berpengaruh positif pada pengungkapan Corporate Social Responsibility perusahaan pertambangan di BEI periode 2015-2017. Jadi hasil penelitian ini sesuai dengan hipotesis ketiga yaitu kepemilikan publik berpengaruh positif pada pengungkapan Corporate Social Responsibilityperusahaan pertambangandi BEI periode 2015-2017. Hasil penelitian ini sesuai dengan penelitian sebelumnya Dewi (2008), Puspitasari (2009) yang membuktikan bahwa kepemilikan publik memiliki pengaruh positif pada pengungkapan Corporate Social Responsibility. Menurut Puspitasari (2009) dengan adanya tekanan dari pemegang saham, maka perusahaan akan lebih memperhatikan tanggung jawab sosialnya terhadap masyarakat. Semakin besar komposisi saham perusahaan yang dimiliki publik, maka dapat memicu perusahaan melakukan pengungkapan secara luas termasuk pengungkapan CSR.

Perusahaan yang memiliki kepemilikan publik yang tinggi pastinya akan lebih memperhatikan pengungkapan tanggung jawab sosial. Hal tersebut disebabkan karena semakin banyak perusahaan memegang kepercayaan masyarakat maka masyarakat pastinya akan memperhatikan apakah perusahaan tempatnya berinvestasi melakukan tindakan sosial yang mensejahterakan masyarakat dan lingkungan sekitar perusahaan. Sehingga kepemilikan publik yang tinggi akan juga meningkatkan pengungkapan tanggung jawab sosial perusahaan. Hasil penelitian ini menunjukan bahwa kepemilikan publik berpengaruh positif. Artinya, semakin tinggi rasio atau tingkat kepemilikan publik dalam perusahaan diprediksi akan melakukan tingkat pengungkapan tanggung jawab sosial yang lebih luas.

\section{SIMPULAN}

Berdasarkan hasil analisis pertama dapat disimpulkan bahwa profitabilitas berpengaruh positif pada pengungkapan Corporate Social Responsibility. Rasio profitabilitas yang semakin tinggi menyebabkan pengungkapan Corporate Social Responsibility semakin luas dan meningkat. Hasil analisis kedua yaitu ukuran perusahaan berpengaruh positif pada pengungkapan Corporate Social Responsibility. Perusahaan yang memiliki ukuran besar cenderung melakukan aktivitas yang lebih banyak terhadap stakeholder sehingga memiliki pengaruh yang lebih besar pada pengungkapan Corporate Social Responsibility. Hasil analisis ketiga yaitu kepemilikan publik berpengaruh positif pada pengungkapan 
Corporate Social Responsibility. Perusahaan pertambangan yang kepemilikan publik meningkat menunjukkan semakin besarnya pengungkapan tanggungjawab sosialnya. Perusahaan yang memiliki porsi kepemilikan publik lebih tinggi akan cenderung melakukan lebih banyak pengungkapan sosial karena dinilai memiliki tanggungjawa bsecara moral kepada masyarakat.

Berdasarkan hasil analisis dan simpulan, dapat diajukan saran untuk penelitian selanjutnya dan untuk pihak-pihak yang berkepentingan. Perusahaan pertambangan saat ini sudah diwajibkan menggunakan laporan keberlanjutan (Suistainbility Reporting) yang diatur dalam peraturan Otoritas Jasa Keuangan, dikarenakan penelitian ini masih menggunakan Corporate Social Responsibility maka diharapkan penelitian selanjutnya agar menggunakan Suistainbility Reporting.

\section{REFRENSI}

Ahmad, N. N. N., \& Sulaiman, M. (2004). Environment Disclosure in Malaysia Annual Reports: A legitimacy Theory Perspective. International Journal of Commerce and Management, 14(1), 44-58. https://doi.org/10.1108/10569210480000173

Ambadar, J. (2008). Corporate Social Responsibility (Csr) Dalam Praktik Di Indonesia. Jakarta: PT. Elex Media Komputindo.

Anggraini, R. (2006). Pengungkapan Informasi Sosial Dan Faktor Faktor Yang Mempengaruhi Pengungkapan Informasi Sosial Dalam Laporan Keuangan Tahunan (Studi Empiris pada Perusahaan-Perusahaan yang Terdaftar Bursa Efek Jakarta). In Simposium Nasional Akuntansi IX. Padang.

Brigham, E. F., \& Houston, J. F. (2010). Dasar-Dasar Manajemen Keuangan (1st ed.). Jakarta: Salemba Empat.

Brigham, E. F., \& Houston, J. F. (2011). Dasar-Dasar Manajemen Keuangan Buku 2. Jakarta: Salemba Empat.

Cowen, S. S., Ferreri, L. B., \& Parker, L. D. (1987). The Impact Of Corporate Characteristics On Social Responsibility Disclosure: A Typology and Frequency-Based Analysis, Accounting, Organizations and Society. Accounting, Organizations and Society, 12(2), 111-122. https://doi.org/10.1016/0361-3682(87)90001-8

Dewi, S. C. (2008). Pengaruh Kepemilikan Institusional, Kepemilikan Manajerial,Kebijakan Hutang, Profitabilitas, dan Ukuran Perusahaan terhadap Kebijakan Deviden. Universitas Trisakti Jakarta.

Ebiringa, O., Yadirichukwu, E., Chigbu, E. E., \& Ogochukwu, O. J. (2013). Effect of Firm Size and Profitability on Corporate Social Disclosures: The Nigerian Oil and Gas sector in Focus. British Journal of Economics, Management $\mathcal{E}$ Trade, 3(4), 563-574. https://doi.org/10.9734/BJEMT/2013/5147

Fahmi, I. (2015). Analaisis Laporan Keuangan. Bandung: Alfabeta.

Fahrizqi, A. (2010). Faktor-Faktor yang Mempengaruhi Pengungkapan Corporate Social Responsibility (CSR) dalam Laporan Tahunan Perusahaan. Universitas Diponegoro Semarang.

Hadi, N. (2011). Corporate Social Responsibility. Yogyakarta: Graha Ilmu. 
Hanafi, M., \& Halim, A. (2012). Analisis Laporan Keuangan. Yogyakarta: UPP STIE YKPN.

Indraswari, G. A. D., \& Astika, I. B. P. (2014). Pengaruh Profitabilitas, Ukuran Perusahaan, Dan Kepemilikan Saham Publik Terhadap Pengungkapan CSR. E-Jurnal Akuntansi Universitas Udayana, 9(3), 816-828. Retrieved from https://ojs.unud.ac.id/index.php/Akuntansi/article/view/9769

Kuntari, Y., \& Sulistyani, A. (2007). Pengaruh Karakteristik Perusahaan Terhadap Pengungkapan Tanggung Jawab Sosial dalam Laporan Tahunan Perusahaan Indeks Letter Quality (LQ 45) Tahun 2005. ASET, 9(2), 494-515. https://doi.org/10.24912/ja.v21i3.266

Natalia, D., \& Laksono, E. P. (2013). Pengaruh Mekanisme Good Corporate Governance Terhadap Praktik Earning Managemeny Badan Usaha Sektor Perbankan di BEI 2008-2011. Jurnal Ilmiah Mahasiswa Universitas Surabaya, 2(1), 1-18. Retrieved from https://media.neliti.com/media/publications/189483-ID-none.pdf

Nofandrilla. (2008). Analisis Pengaruh Karakteristik Perusahaan terhadap Kebijakan Pengungkapan Tanggung Jawab Sosial (Studi Empiris pada Perusahaan Pertambangan yang Terdaftar di Bursa Efek Jakarta. Universitas Negeri Sepuluh November Surakarta.

Nugroho, M., \& Yulianto, A. (2015). Pengaruh Profitabilitas Dan Mekanisme Coporate Governance Terhadap Pengungkapan CSR Perusahaan Tedafrae JII 2011-2013. Accounting Analysis Journal, 4(1), 1-12. https://doi.org/10.15294/aaj.v4i1.7829

Oktariani, W. (2013). Pengaruh Kepemilikan Publik, Ukuran Dewan Komisaris, Profitabilitas Dan Umur Perusahaan Terhadap Tanggung Jawab Sosial Perusahaan. Jurnal Ilmiah Wahana Akuntansi, 8(2), 100-117. Retrieved from http://journal.unj.ac.id/unj/index.php/wahanaakuntansi/article/view/857

Purwaningsih, R. P., \& Suyanto. (2015). Pengaruh Profitabilitias dan Leverage Terhadap Pengungkapan Corporate Social Responsibility (CSR) Perusahaan. Syariah Paper Accounting FEB UMS, 1(1), 133-140. Retrieved from

https://publikasiilmiah.ums.ac.id/bitstream/handle/11617/6080/B.4.pdf;s equence $=1$

Purwanto, A. (2011). Pengaruh Tipe Industri,Ukuran Perusahaan, Profitabilitas, Terhadap Corporate Social Responsibility. Jumal Akuntansi $\mathcal{E}$ Auditing, 8(1), 12-29. Retrieved from http://ejournal.undip.ac.id/index.php/akuditi/ article/view/4344/3963

Puspitasari, A. D. (2009). Faktor-Faktor yang MempengaruhiPengungkapan Corporate Social Responsibility (CSR) pada LaporanTahunan Perusahaan di Indonesia. Universitas Diponegoro Semarang.

Putra, E. N. (2011). Pengaruh Karakteristik Perusahaan Terhadap Pengungkapan Corporate Social Responsibility (CSR). Universitas Diponegoro Semarang.

Rahman, A., \& Widyasari, K. N. (2008). The Analysis of Company Characteristic Influence Toward CSR Disclosure: Empirical Evidence of Manufacturing Companies Listed in JSX. Jurnal Akuntansi E Auditing Indonesia, 12(1), 25-35. Retrieved from https://journal.uii.ac.id/JAAI/article/view/37/134 
Rahmawati, I. D. U. (2005). Pengaruh Ukuran Perusahaan, Ukuran Dewan Komisaris, Kepemilikan Institusional, Kepemilikan Asing, dan Umur Perusahaan, Terhadap Corporate Social Responsibility Disclosure pada Perusahaan Property dan Real Estate yang Terdaftar Di Bursa Efek Indonesia. In Simposium Nasional Akuntansi VIII. Solo.

Retno, R. D., \& Priantinah, D. (2012). Pengaruh Good Corporate Governance Dan Pengungkapan CorporateSocial Responsibility Terhadap Nilai Perusahaan. Nominal, I(1), 84-103. http://dx.doi.org/10.21831/nominal.v1i2.1000

Sari, R. A. (2012). Pengaruh Karakteristik Perusahaan Terhadap Corporate Social Responsibility Disclosure Pada Perusahaan Manufaktur yang Terd aftar di Bursa Efek Indonesia. Nominal, 1(1), 124-140. https://doi.org/ 10.21831/nominal.v1i2.1002

Sembiring, E. R. (2005). Karakteristik Perusahaan dan Pengungkapan Tanggung Jawab Sosial. In Simposium Nasional Akuntansi VIII. Solo.

Siregar, S. V., \& Utama, S. (2008). Type of Earnings Management and The Effect of Ownership Structure, Firm Size, and Corporate Governance Practices: Evidence From Indonesia. The International Journal of Accounting, 43(1), 1-27. https://doi.org/10.1016/j.intacc.2008.01.001

Sumanti, J. C., \& Mangantar, M. (2015). AnalisisKepemilikan Manajerial, Kebijakan Hutang Dan Profitabilitas TerhadapKebijakan Dividen Dan Nilai Perusahaan Pada Perusahaan Manufaktur YangTerdaftar Di BEI. Jurnal EMBA， 3(1), 1141-1151. Retrieved from https://ejournal.unsrat.ac.id/index.php/emba/ article/viewFile/7928/7489

Veronica, T., \& Sumin, A. (2010). The Effect Of Company Charactheristic On Disclosure Of Social Responsibility InMining Corporate Sector Listed In Indonesia Stock Exchange. Jurnal Akuntansi Dan Keuangan, 12(1), 1-11. Retrieved from https://www.researchgate.net/publication/277154662_ The_Effect_Of_Company_Charactheristic_On_Disclosure_Ofsocial_Respons ibility_In_Mining_Corporate_Sector_Listed_In_Indonesia_Stock_Exchange

Wakidi, R. H., \& Siregar, H. S. (2011). Pengaruh Sisi Internal Dan Sisi Eksternal PerusahaanTerhadap Pengungkapan Tanggung JawabSosial Perusahaan Pada Perusahaan Yang TerdaftarDi BEI. Jurnal Ekonom, 14(4), 180-190. Retrieved from http://repository.usu.ac.id/bitstream/handle/123456789/31146/wakidi hasan sakti.pdf?sequence $=1$ \&isAllowed $=\mathrm{y}$

Wijaya, M. (2012). Faktor-faktor yang Mempengaruhi Penungkapan Tanggung Jawab Sosial Perusahaan Manufaktuf yang Terdaftar di Bursa Efek Indonesia. Universitas Lampung. Retrieved from https://www.coursehero.com/file / p5tckre6/Skripsi-Universitas-Lampung-Maria-Wijaya-2012-Faktor-Faktoryang-Mempengaruhi/

Zaenuddin, A. (2007). ). Faktor-Faktor Yang Berpengaruh Terhadap Praktek Pengungkapan Sosial Dan Lingkungan Pada Perusahaan Manufaktur Go Publik. Universitas Diponegoro Semarang. 